\title{
Zdokonalení systému kontinuálního monitorování radioaktivní kontaminace povrchových vod využitím výpočetního algoritmu
}

\section{MICHAL FEJGL, MIROSLAV HÝŽA}

Klíčová slova: spektrometrie gama - Nal(TI) - monitorování radiační situace havarijní monitorování - ${ }^{137} \mathrm{Cs}$ - přenos bázových komponent

\section{SOUHRN}

Stat’ popisuje praktické aspekty uplatnění algoritmu NASVD při zpracování gama spekter ze sítě kontinuálních monitorovacích stanic gama aktivity v říční vodě (SAGMA) s důrazem na přenos bázových komponent mezi různými lokalitami. V minulosti byl vliv dekonvoluční metody NASVD na zlepšení citlivosti SAGMA ověěen v poloterénních podmínkách. Po umístění sítě prístrojů SAGMA do reálných říčních podmínek byla metoda NASVD použita také na spektra z těchto prístrojů. Za tímto účelem byl experimentálně proveden přenos konvergovaných bázových komponent pozad’ových spekter z poloterénního provozu. Výsledky ukázaly dobrou přenositelnost pozad’ové báze v rámci podmínek tekoucí říční vody za dodržení patřičné hloubky ponoru sondy. Pro podmínky stojaté přehradní vody nebyl přenos proveden úspěšně. Ukazuje se, že SAGMA může za dodržení patřičných vlastností monitorovací lokality fungovat také jako mobilní monitorovací stanice s možností využít metodu NASVD okamžitě po umístění na novou lokalitu bez nutnosti zdlouhavého nabírání trénovacích spekter.

\section{ÚVOD}

Za účelem zlepšení havarijní připravenosti České republiky byl vyvinut monitorovací systém určený ke kontinuálnímu in situ stanovování aktivity gama $\checkmark$ povrchových vodách. Monitorovací systém sestává z monitorovacích stanic nazývaných akronymem SAGMA (z anglického Station for Artificial Gamma Activity Measurement). Jsou to monitorovací stanice fungující na bázi ponorného Nal(TI) detektoru měříího ve $4 \pi$ geometrii prímo $v$ mase analyzované vody bez použití stínění. SAGMA je vybaven autonomním zdrojem elektrického napájení a dálkovým přenosem dat, takže splňuje kritéria pro zařazení do skupiny "stand-alone“ prístrojů [1]. Ze tří SAGMA byla sestavena provizorní monitorovací minisít [2], nazývaná akronymem SCOMO (System for Continuous Gamma Acitivy Monitoring).

Konstrukce SAGMA je popsána v článku Fejgla a kol. [1]. Tato monitorovací stanice je unikátní schopností pracovat v autonomním a automatickém režimu, což je výhodné v prípadě havarijního monitorování, pro jehož potřeby je primárně určena. Oproti dalším přístrojům stejného určení popsaným v literatuře vykazuje SAGMA vyšší citlivost detekce [1, 3, 4]. To je zajištěno použitím dekonvolučního algoritmu NASVD (Noise Adjustment Singulat Value Decomposition), umožňujícím získání bázových spekter z výsledků měření pozadí, a tím redukovat vliv odezvy detektoru na kolísání prírodního pozadí [5].

Kolísání príspěvku gama od pozadí je v prípadě kontinuálního in situ měření gama aktivity říčních vod způsobeno především kolísáním aktivity radonu a jeho přeměnových produktů. Vzhledem k tomu, že radon a jeho preměnové produkty jsou obsaženy prímo v analyzované vodě, toto kolísání ovlivňuje i analýzy vod prováděné nejen pomocí prístrojů s ponornou detekční sondou, ale i pomocí prístrojů vybavených stíněnou detekční komorou, například kontinuální monitorovací stanice vybavené stíněnou Marinelliho nádobou [3]. V prípadě ponorných monitorovacích stanic dochází také k významnému kolísání dalších složek příspěvku do pozad’ové odezvy, a to kosmického záření zejména $v$ souvislosti s kolísáním vodní hladiny a terestriálního záření v souvislosti s kolísající vzdáleností sondy ode dna a se složením dnových sedimentů. Následkem těchto vlivů jsou monitorovací stanice využívající konstrukci ponorné sondy oproti monitorovacím stanicím se stíněnou detekční komorou méně citlivé $[1,3,4]$.

Využití algoritmu NASVD pro potřeby SAGMA bylo testováno umístěním detekční sondy prístroje do poloterénních podmínek v areálu VúV TGM v Praze [1]. Spektra z dlouhodobého, přibližně jednoletého, kontinuálního měření byla použita jako tréninkový dataset pokrývající celosezonní kolísání pozadí pro tuto lokalitu. Využitím z něj vygenerovaných bázových komponent pozadí metodou NASVD přineslo velice príznivé výsledky, jmenovitě pokles hodnot NDA približně na polovinu oproti srovnatelné monitorovací stanici vybavené ponornou sondou $[1,4]$. Ve srovnání s monitorovací stanicí se stíněnou průtočnou měřicí komorou jsou při desetiminutovém integračním čase v případě SAGMA hodnoty NDA navýšeny faktorem přibližně 1,4 [1,3]. Dále bylo shledáno, že desetiminutový integrační čas i za nejméně příznivých okolností postačuje k naplnění zákonných požadavků na havarijní monitorování umělé aktivity gama, tedy ${ }^{137} \mathrm{Cs}$ a ${ }^{131}$ [6]. Takto významné zvýšení citlivosti bylo umožněno právě získáním bázových komponent z dlouhodobého pozad’ového datasetu pokrývajícího v podmínkách dané lokality všechna roční období [1].

V období od června do řína 2019 bylo uskutečněno zprovoznění tři SAGMA $\checkmark$ prostředí reálných říčních podmínek. Jednotlivé SAGMA byly umístěny do monitorovacích bodů vybraných jako vhodné lokality k monitorování aktivity 
gama v řekách ČR z hlediska potenciálního přínosu pro připravenost k odezvě na mimořádnou radiační událost. Tím byla vytvořena provizorní forma monitorovací sítě SCOMO [2]. Okamžikem zprovoznění jednotlivých SAGMA bylo zahájeno nepřetržité měření a odesílání změených spekter systémem dálkového přenosu na server. Integrační čas měření i interval odesílání jsou nastaveny na hodnotu 10 minut.

Po šesti až deseti měsících provozu jednotlivých stanic v rámci minisítě byla provedena srovnávací analýza pozad’ových spekter, jejímž cílem bylo stanovit detekční citlivost jednotlivých SAGMA stanic a prověřit přenositelnost bázových komponent pozadí mezi monitorovacími lokalitami bez nutnosti zdlouhavého měření pozadí v daném místě.

\section{POPIS LOKALIT}

Provizorní podoba monitorovací minisítě SCOMO sestává ze tři SAGMA umístěných $v$ monitorovacích lokalitách na řekách České republiky. Jsou to tárovací kanál Vúv TGM v Praze na řece VItavě (dále jen Praha), náhon vodní elektrárny Na Réně v Ivančicích na řece Jihlavě (Ivančice) a výpust přehradní nádrže Kořensko na řece VItavě (Kořensko).

Lokality Praha a Ivančice mají z hlediska hydrologických poměrů podobné vlastnosti, sonda je zanořena do kanálu o hloubce přibližně 2 metry, dno kanálu je vybetonované a vodní hladina se nachází v relativně stabilní úrovni přibližně $80 \mathrm{~cm}$ nad horní hranou detektoru. Kanálem protéká mělká voda rychle proudících řek VItava, resp. Jihlava. Lokalita Kořensko vykazuje zcela odlišné hydrologické vlastnosti, je umístěna v boční stěně přehradní nádrže Kořensko ve vzdálenosti približně 8 metrů po proudu od výpusti z přehrady. Spodní hrana sondy je umístěna asi 1,5 metru nad vybetonovaným dnem kanálu, horní hrana sondy je od hladiny vzdálena 2 až 6 metrů, protože hladina vody během sezony značně kolísá. Kanálem protéká stojatá voda z prehradní nádrže Kořensko. Vypouštěná voda se bezprostředně před vypuštěním nacházela ve hloubce dvou a více metrů pod hladinou prehradní nádrže.

\section{PŘENOS BÁZOVÝCH KOMPONENT - DISKUSE A VÝSLEDKY}

Metodou NASVD byly z trénovacích spekter z lokality Praha získány bázové komponenty popisující pozadí v lokalitě VúV TGM (lokalita Praha byla použita jako referenční lokalita, dále jen referenční bázová spektra). Obdobně byla zpracována měření z Ivančic a Kořenska, čímž byly získány lokální bázové komponenty pozadí. Vzhledem k odlišnostem v nastavení a typu elektroniky byla před samotnou NASVD analýzou spektra přeškálována tak, aby si odpovídaly četnosti v jednotlivých kanálech spekter z různých lokalit.

Získané bázové komponenty byly použity pro fitování spekter v testovacím datasetu za použití lineárního regresního modelu. $\vee$ modelu byly použity jak lokální, tak referenční bázové komponenty a následně bylo provedeno srovnání výsledků pomocí standardní chyby reziduí (RMSE) pro soubor testovacích spekter, viz obr. 1 .

Pro spektra z lokality Ivančice bylo dosaženo poměrně dobré shody a související navýšení MDA pro vybrané radionuklidy $\left({ }^{131} 1,{ }^{134} \mathrm{Cs},{ }^{137} \mathrm{Cs}\right)$ je rovněž přijatelné - $v$ testovacím datasetu nepřevyšuje 10 až $15 \%$. Odlišná je situace pro spektra z Kořenska - vzhledem k hloubce uložení a tedy i vyššímu podílu rozptýleného záření a nižšímu vlivu dceřiných produktů radonu se spektra z Kořenska kvalitativně liší od zbylých dvou lokalit. Fitování pomocí referenční báze selhává a metoda je pro tuto lokalitu nepoužitelná. Srovnání středních spekter z jednotlivých lokalit ilustruje obr. 2.

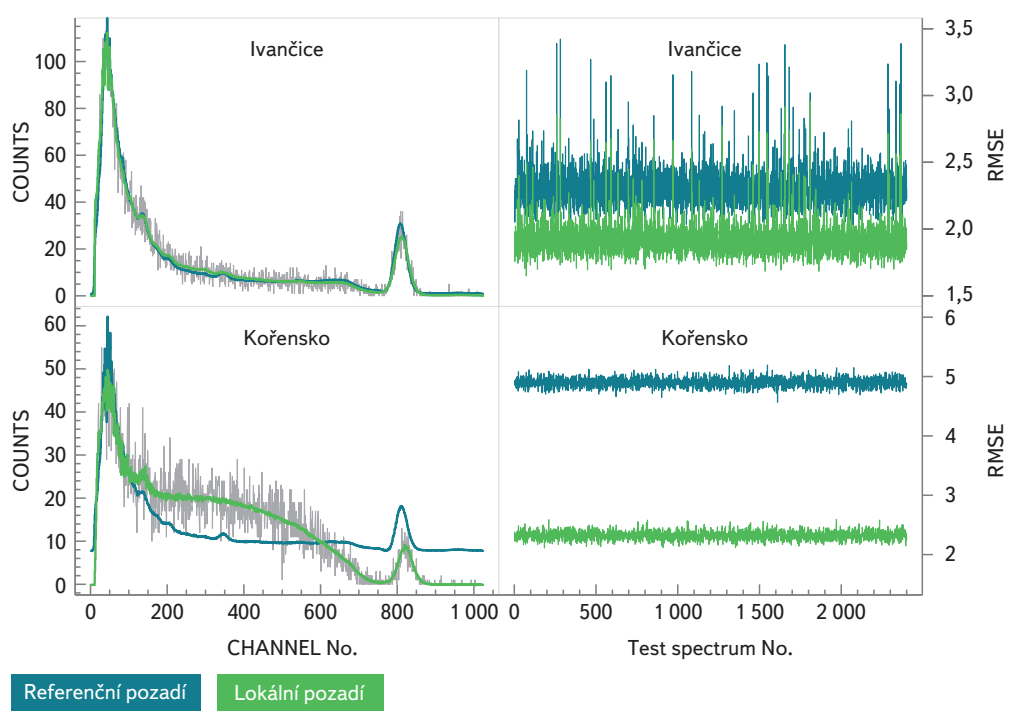

Obr. 1. Vlevo - ukázka fitu referenčními a lokálními bázovými komponentami v Ivančicích a Kořensku (integrační doba 3600 s); vpravo - související průběh RMSE napříc testovacím datasetem

Fig. 1. Left - demonstration of local base component fit for the spectra from Ivančice and Kořensko (integration time 3600 s); right - related course RMSE across the testing dataset

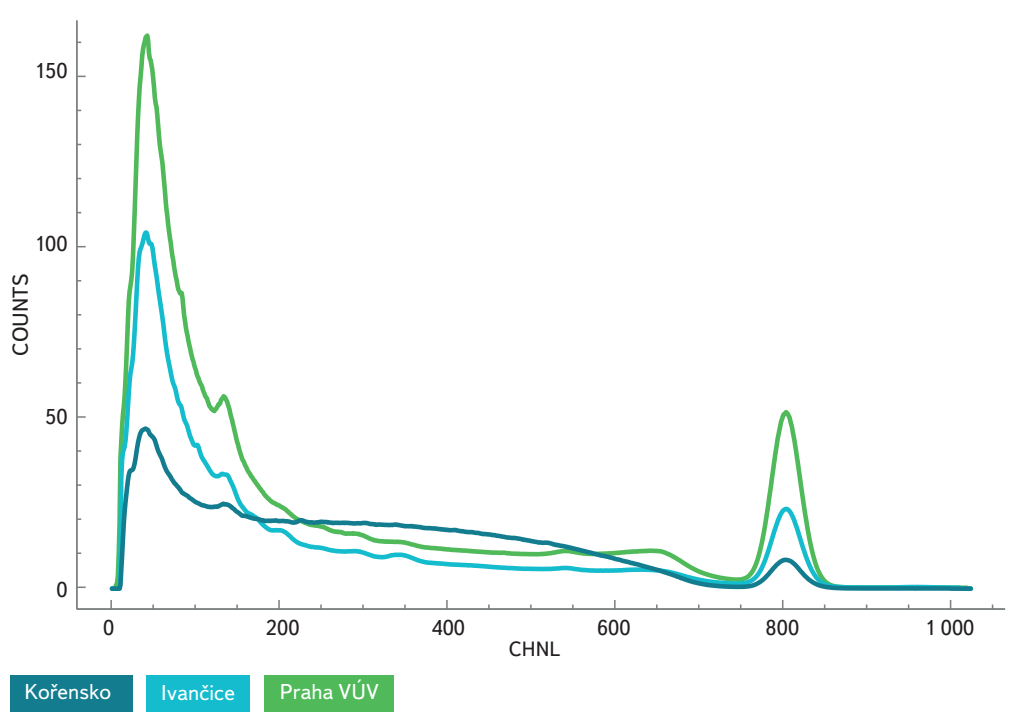

Obr. 2. Střední spektra z jednotlivých lokalit; spektrum Kořensko vykazuje odlišný průběh oproti lokalitám Praha a Ivančice

Fig. 2. Mean spectra from the individual location; spectra from the location Kořensko demonstrates different course compared to the locations Prague and Ivančice

Dále byla lokální bázová spektra z Ivančic a z Kořenska použita pro výpočet hodnot NDA v těchto lokalitách. Tyto hodnoty jsou v prípadě Ivančic přibližně o 40 a v prípadě Kořenska o 75 \% nižší než v lokalitě Praha [1]. V tabulce 1 jsou uvedeny typické hodnoty NDA objemové aktivity pro ${ }^{137} \mathrm{Cs}$ při použití jednohodinového integračního času. Pro ilustraci jsou použita data z množiny "všechna spektra" $[1,2]$.

Vyšší citlivost SAGMA při umístnění v lokalitách Ivančice a Kořensko je dána především hydrologickými poměry $v$ daných lokalitách (vyšším průtokem), v lokalitě Kořensko také umístěním sondy do větší hloubky. 
Tabulka 1. Typické hodnoty objemové aktivity NDA pro ${ }^{137} \mathrm{Cs}$ prí použití NASVD metody pracujicís lokálními bázovými komponentami, integrační čas 1 hodina

Table 1. Minimal detectable activity values for ${ }^{137} \mathrm{Cs}$ activity concentration typical for the individual locations; integration time is 60 minutes, NASVD deconvolution method is employed

\begin{tabular}{llll} 
Lokalita & Praha & Ivančice & Kořensko \\
\hline NDA $[\mathrm{Bq} / \mathrm{L}]$ „Všechna spektra“ & 0,83 & 0,50 & 0,21
\end{tabular}

\section{ZÁVĚR}

Přenos bázových komponent pozadových spekter z referenční lokality se ukazuje jako efektivní metoda pro hodnocení spekter po dobu, kdy ještě pro danou lokalitu není k dispozici dostatečně velký počet $\left(\sim 10^{4}\right)$ spekter pro vytvoření bázových komponent. Podmínkou přenositelnosti je, že obě lokality vykazují podobné hydrologické charakteristiky a zároveň je dodržena podobná geometrie měření. To $v$ prípadě popisované situace znamená ponoření sondy do volně tekoucí ríční vody do hloubky $>1 \mathrm{~m}$.

Dále je možné metodu výhodně doplnit o kontinuální updatování NASVD po instalaci sondy v nové lokalitě je nejprve použit model s referenčními bázovými komponentami, který se s príibývajícími lokálními spektry postupně přizpůsobuje místním podmínkám. Pro tyto účely existují poměrně efektivní výpočetní algoritmy, které lze ještě dále urychlit pomocí paralelizace [6]. SAGMA byla koncipována jako „stand-alone“ monitorovací stanice odolná vưči následkům mimořádné radiační události. Vzhledem $k$ jednoduchosti konstrukce je možné SAGMA použít také jako přenosnou monitorovací stanici. Naše předchozí publikace [1] předpokládá, že premístění systému na novou lokalitu znemožňuje plné využití metody NASVD pro zvýšení citlivosti systému, dokud nedojde k nahromadění tréninkového datasetu pokrývajícího celosezonní přirozené variace pozadí.

Experimentální přenos referenčních bázových komponent pro účely použití NASVD na spektra z jiné lokality prokázal, že za dodržení charakteristických podmínek monitorovací lokality NASVD Ize metodu účinně využít i po přemístění SAGMA na novou lokalitu, a to s překvapivě nízkým, maximálně 15\% navýšením detekčních mezí. SAGMA tím získává uplatnění také jako mobilní monitorovací stanice. To navyšuje flexibilitu SCOMO v rámci jeho plánovaného uplatnění v systému připravenosti k odezvě na mimořádnou radiační událost. Za nejméně příznivých podmínek (po bouřích či průtržích mračen) v rámci tří studovaných lokalit je při použití přenesených bázových komponent hodnota NDA pro stanovení objemové aktivity ${ }^{137} \mathrm{Cs}$ při desetiminutovém integračním čase maximálně 2,6 Bq/L.

Oproti stíněným průtočným monitorovacím stanicím jsou hodnoty NDA při využití NASVD s přenesenými bázovými komponentami pro ${ }^{131}$ a a ${ }^{137} \mathrm{C}$ s navýšeny přibližně faktorem 1,6, zatímco oproti jiným monitorovacím stanicím využívajícím ponornou sondu pracujícím s Nal(TI) detektorem jsou hodnoty NDA sníženy přibližně faktorem $1,8[3,4]$. Je třeba zdưraznit, že konstrukce žádné ze srovnávaných monitorovacích stanic není vhodná k okamžitému přemistování mezi lokalitami, a to především kvưli závislosti na zdroji elektrického napájení či kvůli absenci dálkového přenosu dat.

Prenos bázových spekter pro podmínky hluboké vody je problematický. Zároveň je třeba zdưraznit, že pro potřeby havarijního monitorování jsou podmínky hluboké vody všeobecně méně vhodné (nedochází k prudkým fluktuacím objemové aktivity po kontaminaci), a tak pro tento typ lokality není použití SAGMA jako mobilní monitorovací stanice relevantní. Na druhou stranu SAGMA umístěná $v$ hluboké tekoucí vodě dosahuje mimořádně nízkých detekčních mezí při použití lokálních bázových komponent (viz tabulka 1, lokalita Kořensko). $\checkmark$ těchto podmínkách je systematicky dosahováno citlivosti potřebné pro splnění legislativního požadavku na stanovení objemové aktivity ${ }^{137} \mathrm{Cs}(0,1 \mathrm{~Bq} / \mathrm{L}$ podle [6]) při použití integračního času 24 hodin.

Od května 2020 je SCOMO v rámci implementačního plánu provozováno jako doplňkový prostředek pro analýzy vod v rámci MRS. Srovnáním s př́stroji popsanými v literárních zdrojích je možné SCOMO považovat za "State of the art" prostředek pro havarijní monitorování aktivity gama v povrchových vodách.

\section{Poděkování}

Výzkum byl podpořen projektem Ministerstva vnitra České republiky (projekt VI20172020083)

\section{Literatura}

[1] FEJGL, M. and HÝŽA, M. Development of an autonomous station for measurements of artificial gamma activity in surface water bodies. J. Environ. Radioact., 2019, 204, p. 42-48.

[2] FEJGL, M., HÝŽA, M. a HŮLKA, J. Systém pro kontinuální monitorování radioaktivní kontaminace povrchových vod. VTEl, 2019, č. 6, s. 32-39.

[3] CASANOVAS, R., MORANT, J.J., and SALVADÓ, M. Implementation of gamma-ray spectrometry in two real-time water monitors using Nal(TI) scintillation detectors. Appl. Radiat. Isot., 2013, 80, p. 49-55.

[4] STEINMANN, P. Radioactivity in river water below nuclear plants, the new network monitors the Aare and the Rhine on an ongoing basis. Aqua \& gas, 2013, 10.

[5] MINTY, B. and HOVGAARD, J. Reducing noise in gamma-ray spectrometry using spectral component analysis. Explor. Geophys., 2002, Vol. 33, No. 3, p. 172-176.

[6] SÚJB 360/2016 Sb. Vyhláška o monitorování radiační situace. 2016

[7] YAMAZAKI, I., KURZAK, J., LUSZCZEK, P., and DONGARA, J. Randomized algorithms to update partial singular value decomposition on a hybrid CPU/GPU cluster. International Conference for High Performance Computing, Networking, Storage and Analysis, SC, 1-12. Dostupné z: https://doi. org/10.1145/2807591.2807608.2015

\section{Autoři}

Mgr. Michal Fejgl, Ph.D.

$凶$ michal.fejgl@suro.cz

ORCID: 0000-0002-6207-297X

Ing. Miroslav Hýža

凶miroslav.hyza@suro.cz

ORCID: 0000-0001-6719-1524

Státní ústav radiační ochrany, v. v. i.

Príspěvek prošel lektorským řízením.

DOI: 10.46555/VTEI.2020.05.004 


\section{A COMPUTATIONAL ALGORITHMS USED FOR IMPROVEMENT OF THE SYSTEM FOR CON- TINUOUS MONITORING OF RADIOACTIVE CONTAMINATION OF SURFACE WATERS}

\section{FEJGL, M.; HYZA, M.}

National Radiation Protection Institute, p.r.i.

Keywords: gamma spectrometry - Nal(TI) monitoring of radiation situation - emergency monitoring -

${ }^{137} \mathrm{Cs}$ - portable monitoring station

The article describes practical aspects of the NASVD algorithm application in the processing of gamma spectra from the network of stations for continuous monitoring of gamma activity in river water (SAGMA). Transfer of base components between different localities is emphasised in the article. In the past, the effect of the NASVD deconvolution method on the improvement of SAGMA sensitivity was verified in semi-field conditions. After placing the network of SAGMA instruments in real river conditions, the NASVD method was applied for data processing again. For this purpose, the transfer of converged spectral components of the background spectra from semi-field operation was performed experimentally. The results showed good transferability of the background spectral components from the sites of running river water while maintaining the appropriate depth of immersion of the probe. For standing dam water conditions, the transfer was not successful. These results show, that SAGMA can be also operated as a mobile monitoring station, while maintaining the appropriate characteristics of the monitoring site. The NASVD method can be used immediately after placement in a new site without the need for lengthy acquisition of training spectra. 